\title{
The Emergence of Educational Technology
}

\author{
Elizabeth $\mathrm{Koh}^{1}$ and John Lim $^{2}$ \\ 1 Department of Information Systems, School of Computing, \\ National University of Singapore; diskre@nus.edu.sg \\ 2 Department of Information Systems, School of Computing, \\ National University of Singapore; jlim@nus.edu.sg
}

\begin{abstract}
This paper traces the emergence of Information Technology (IT) for educational purposes. It begins with a discourse on the relationship between culture and educational technology. A key premise is that culture is an important influence in education. Similarly, the evolution of educational technology is very much intertwined with culture. This paper traces educational development from the traditional times to modern times. Educational technology was initially viewed as technology in education, a sole focus on IT tools. Subsequently, a holistic perspective of the educational system was adopted, termed the technology of education. In this larger view, educational technology is informed by research from learning theories and other educational research. The paper elaborates on these theoretical underpinnings with some examples of educational technology before concluding with implications for practitioners and researchers.
\end{abstract}

Keywords: Educational technology, E-learning, Online education, Culture, History of education

\section{Introduction}

Computing power and technologies have been developing rapidly in the present century. Fuelled by the knowledge economy, IT and education are forecast to become one of the biggest sectors in the world. We can see this rise in computing and education as originating from its cultural roots. To understand educational technology, we first have to realize what education is. In this article, we trace the history of educational technology. We premise that culture is an important influence in education. Following which, we describe the evolution of educational thoughts and pedagogy. The next section surmises the history of educational technology with examples. The paper then concludes with implications for practitioners and researchers. 


\section{Cultural Basis of Education}

Since the beginning of civilization, education has been the inculcation of wisdom and knowledge, the passing down of traditions and values from one generation to the next. Since culture is the totality of socially transmitted behavior patterns, arts, beliefs, institutions, and all other products of human work and thought (Ferrante 2003), education is actually the process of transmitting culture. Education and culture are "interwoven and inseparable" (McLoughlin 1999, p.232). Culture influences the course of education. We now trace the developments of education and culture from ancient times to the modern day.

\subsection{Cultural Underpinnings of Ancient Education}

To educate, in Latin stems from the term "educare" with its root meaning to "lead forth" (Oxford English Dictionary 1989). The Latin word also implies a change brought about by practice or usage (Sharma 1987). The leading out of an individual has been formalized by society through educational systems and the induction of a curriculum. The earliest known educational systems originate from the ancient cultures of Greece, China and India. The structure of each educational system is based on each country's educational philosophies at that time.

In ancient China, education was a means of social unity and harmony (Cleverly 1991). In particular, the teachings of the sage Confucius heavily influenced educational ideals. He encouraged the learning of subjects through a long, detailed study with a good teacher. Good education should be open to all who will gain from it. The aim was not to impart knowledge or transmit skills but to improve the character of students (Cheng \& Wong 1996). Students were produced to be full of grace and integrity, conscientious and altruistic, and to serve the society.

Since the Han dynasty (206BC-AD220), the Chinese instituted examinations for scholars wanting to enter the civil service. They rewarded greatly scholars who fared well in these examinations in terms of social standings and social mobility. This has led East Asians to have a high reverence for examination and competition (Cheng \& Wong 1996). Ancient Chinese philosophy also emphasized selfinstruction and learning from others; however, critical thinking was absent (Turner \& Acker 2002). In fact, conformity was the norm and traditional scholars were taught to "compile rather than to compose" (Cheng \& Wong 1996, p.42). These educational philosophies from ancient China have influenced how many East Asian countries view education.

On the other hand, educational philosophy in olden India was a spiritual affair as it was shaped by religious ideals. Indian culture regards divinity as the ultimate level of development (Sharma 1987). Education is regarded as a source of illumination. It is an inner discipline to gain the emancipation of the soul (Pathak 2002). The educational system was called Gurukul in which a student would live with his guru and learn from him through rigorous self-discipline over a long 
period of time (Sharma 1987). The goal was to develop a disciple that was physically, mentally, and spiritually equipped - and a good citizen.

The ancient Greeks were the "first real educators" of the western world (Castle 1965, p.11). The Greeks founded gymnasiums that became both a place for athletics, military training, and a centre for learning (Camp \& Fisher 2002). Schools were recognized synonymously with their teachers (Cribiore 2001). The teachings of early Greek philosophers such as Socrates, Plato and Aristotle, have shaped Western aims in education. For example, from Plato, education is the imparting of information and redirection of the student to the knowledge of good; for students to be truth seekers (Gutek 1997). He viewed education as a means of developing the natural abilities of students. Moreover, these abilities would enable students to find satisfaction in their work and serve the needs of the state (Ellis, Cogan \& Howey 1991). However, since education was privatized, only the rich and powerful could afford to receive a full education (Castle 1965). Poorer pupils only went to school for a few years (Castle 1965). Cribiore (2001) adds that the education system in ancient Greece was a "steep hill" that students climb to reach the summit. Many were unable to overcome obstacles and thus only a handful of pupils make it to the top.

Despite the different educational goals and subject matter, the ancient educational systems typically followed the master-disciple model (Cochrane 1998) or the apprentice model (Honebein, Duffy \& Fishman 1993). The disciple or the apprentice learns a task like masonry or "thinking" under the instruction of an expert (Honebein et al. 1993). Honebein et al. (1993) observes that the driving force in these ancient cultures is to obtain work. Similarly McPherson and Nunes (2004) add that students of ancient times learned tasks and skills not for distant or symbolic goals (such as an educational certificate), but for its immediate value in getting the work done. These ancient educational structures were also alike in that only select pupils were privileged enough to be educated by a small number of available teachers (Cochrane 1998). In other words, the elite such as the wealthy and powerful in these nations were usually much more educated than the poor were.

The next section describes the changes to ancient educational structures primarily due to the invention of modern technology such as the printing press.

\subsection{Traditional Education}

The invention of the printing press led to massive changes in the education system (Cochrane 1998; McPherson \& Nunes 2004). People could learn about the real world from an intellectual distance through the written word (McPherson \& Nunes 2004). Moreover, the Industrial Revolution and widespread migration led to the creation of mass education (Cochrane 1998; Ferrante 2003) and the demise of the apprenticeship model (Honebein et al. 1993). It was first introduced by the United States in 1852 in the state of Massachusetts (Ferrante, 2003). By 1910, elementary school education was compulsory for all U.S. states. 
Moreover, a new set of educational ideas started to influence education. Western educational philosophies originating primarily from America and parts of Europe can be classified into five schools of thoughts - perennialism, essentialism, progressivism, reconstructionism, and existentialism. An overview of these five educational philosophies appears in Table 1 (Ellis et al. 1991, p.103). A full discourse of these western philosophies is too wide for the scope of the paper. Refer to Ellis and colleagues (1991) for further information. These educational philosophies from Western cultures have dominated the research of education and learning.

Table 1 Overview of Educational Thought

\begin{tabular}{llcc}
\hline $\begin{array}{l}\text { Educational } \\
\text { Viewpoint }\end{array}$ & Philosophic Base & Role of Teacher & Purpose \\
\hline $\begin{array}{l}\text { Perennialism } \\
\text { Essentialism }\end{array}$ & Idealism/Realism & $\begin{array}{c}\text { Teacher as an example of } \\
\text { values and ideals }\end{array}$ & Absorption of ideas \\
& Neo-Thomism & $\begin{array}{c}\text { Teacher as mental } \\
\text { disciplinarian and } \\
\text { moral/spiritual leader }\end{array}$ & $\begin{array}{c}\text { Absorption and } \\
\text { mastery of facts and } \\
\text { skills }\end{array}$ \\
$\begin{array}{l}\text { Progressivism } \\
\text { Reconstruc- }\end{array}$ & Experimentalism/Pragmatism & $\begin{array}{c}\text { Teacher as challenger and } \\
\text { inquiry leader }\end{array}$ & $\begin{array}{c}\text { Problem solving and } \\
\text { social experience }\end{array}$ \\
tionism & Experimentalism/Pragmatism & $\begin{array}{c}\text { Teacher as project director } \\
\text { and research leader }\end{array}$ & $\begin{array}{c}\text { Problem solving and } \\
\text { rebuilding the social } \\
\text { order }\end{array}$ \\
Existentialism & Existentialism & Teacher as non-interfering \\
sounding board & Searching for self
\end{tabular}

Modern developments such as the establishment of the scientific inquiry, led to the study of higher mental processes of how people learn. Research in educational psychology produced theories of learning which have perpetuated into many cultures. Unlike philosophies that specify learning goals, learning theories focus more on the process of learning. There is a whole spectrum of learning theories and their derivations but the primary ones in traditional education are the behaviorist learning theory and cognitive information processing.

The earliest learning theory is the behaviorist learning theory. Also called objectivism, it is based on "Thorndike's connectionism, Pavlov's classical conditioning and Skinner's operant conditioning" (Williams 2002, p.134). It was the traditional belief system around the world. The central tenet is that we can learn or enforce target behavior through repetition and correction. Three other core principles are the need for objectives, learning through activity and reinforcement through rewards or punishments (Taylor \& Furnham 2005). Education is a process of knowledge transfer from the expert teacher to the novice student. 
While behaviorism concentrates on external stimuli, a new model was developed, known as cognitivism or cognitive information processing. Among its proponents are Jean Piaget and Jerome Bruner (Driscoll \& Carliner 2005). Cognitivism holds that learning is a change in the cognitive structures of the mind and occurs when informational input is received and processed (Boettcher \& Conrad 2004). Students learn better through linking prior knowledge, relationships between concepts, well-categorized materials, feedback, catering to the students' learning style and the engagement of many perceptions as possible (Taylor \& Furnham 2005; Leidner \& Jarvenpaa 1995).

Traditional education is hallmarked by its face-to-face component in classroom settings. Students tend to learn by themselves (Garrison \& Anderson 2003) and absorb information passively from the teacher (Gillespie 1998). Moreover, the instructional approach is focused on the teacher who is the main source of knowledge. The teacher engages in didactic teaching and assesses students on their memory and knowledge (Gillespie 1998).

\subsection{Modern Education}

While traditional education is based on behaviorist learning theory and cognitive information processing, modern education is evolving to a new paradigm, termed constructivism. It is heavily influenced by Dewey's ideas of self-directed learning (Strijbos et al. 2004). Constructivism perceives learning from the locus of learners rather than educators (Tomei 2005). Constructivism holds that the creation of knowledge is based on the learner reflecting on his own experiences (Driscoll \& Carliner 2005). Besides meaning making, another facet of constructivism is the need for authentic contexts (Duffy \& Jonassen 1992) which is also called situated or distributed cognitions (Jonassen, Hernandez-Serrano \& Choi 2000). It emphasizes that the social world around them, their culture, and community influence people's beliefs. Lastly, the constructivist theory of learning is a social nature of knowledge construction (Jonassen et al. 2000). Some theorists have extended the model to become the collaborative learning model that stresses on the role of peer relationships in a learning community as a key component of educational success (Leidner \& Jarvenpaa 1995). As people cooperate, they discuss and share, contributing different understandings that lead to new, shared understandings.

The emergence of constructivism paralleled with the radical changes in educational technology. In addition, the growth of the knowledge economy and the need for new skills is "fueling a transition in modern learning in the era of the Internet" (Zhang et al 2004, p.75). Education in this modern era contains elements of traditional learning - the face-to-face component and virtual learning - learning through electronic means. In fact, some term this modern education to be blended learning, mixed mode learning, or hybrid learning (Ausburn 2004). The following table charts the difference between traditional education and modern education 
with information adapted from Kinder (2002, p.392) and Zhang et al (2004, p.76). (See Table 2).

Modern education is rife with the use of educational technology. A key issue in the development of educational technology is how one can effectively employ it in education. Before looking into this issue, we trace the emergence of educational technology and delve into the function of pedagogy for its theoretical foundation and as a possible solution to determine the effectiveness of educational technology.

Table 2 Differences in traditional and modern education

\begin{tabular}{|l|l|}
\hline Characteristics of traditional learning & Characteristics of virtual learning \\
\hline - Teacher control & - Learner options or control \\
- Structured content & - Exploration (negotiation) of content \\
- Errorless performance sought & - Learn from errors \\
- Small steps & - Large jumps \\
- Liners, limited branching & - Linking \\
- Local & - Global \\
- Transfer of knowledge and specific skills & - Learn problem solving \\
- Teach procedures & - Practice critical thinking skills \\
- Control the learner & - Empower the learner \\
- Immediate feedback & - Time and location flexibility \\
- Familiar to both instructors and students & - Cost-effective for learners \\
- Motivating students & - Unlimited access to knowledge \\
& - Archival capability for knowledge reuse and \\
\hline Traditional instructional approach & sharing \\
\hline - Teacher-directed & Modern instructional approach \\
- Didactic teaching & - Learner-directed \\
- Short blocks of instruction on single subject & - Student exploration \\
- Individual, competitive work & - Extended blocks of multidisciplinary \\
- Teacher as knowledge dispenser & instruction \\
- Ability grouping & - Action and interactive instruction modes \\
- Assessment of knowledge, specific skills & - Collaborative, co-operative work \\
\hline
\end{tabular}

\section{Emergence of Educational Technology}

IT has been used in many diverse and innovative ways in education contexts, ranging from a simple printing tool to an educational experience via virtual reality. There are two distinct functions of educational technology use - termed the technology in education and technology of education. The first term refers to the tools used in education such as instructional media, hardware and software used to present information (Ellington et al. 1993). The technology in education concept views IT as a silver bullet that will increase the learning of students just by applying educational technology. However, the second term, the technology of education, views the educational system as a whole. It encompasses the intangible 
features from research and learning theories together with the hardware and software portions. The technology of education aims to improve the effectiveness of the teaching and learning process (Ellington et al. 1993). We briefly summarize the manifestation of IT in education.

\subsection{Historical Development of Educational Technology}

Four key technologies - film, television, computers, and the Internet have enabled the utilization of IT for education. Beginning with film, this was utilized in education since the 1940s. For instance, the US military used movies to train its troops (Rosenberg 2001). Soon after, television was used to instruct students. Instructional videos were a central part of the US public school's education in the 1950s and 1960s (Ellington et al. 1993).

In the 1970s, researchers invented the microcomputer that began a new phase for educational technology. Parallel to the widespread usage of IT, the usage of educational technology grew (Matta \& Kern 1989). It also prompted the growth of the educational software industry. The use of computers for education was termed computer-aided instruction (CAI). The development of word processing software and spreadsheet software has enabled computers to become a tool to create educational lessons. Individuals could express their knowledge using these applications. Another development was the commercialization of instructional material. Professionals developed complex and rich instructional materials and these required support staff. Technology became a black box to users. These educational technology integrated text, images, sound, and video into one whole package. Multimedia CD-ROMs proliferated into the market. An example is Microsoft's Encarta. This computerized encyclopedia could possibly be the most well known educational software product during our time (Adelsberger, Collis, \& Pawlowski 2002).

The Internet explosion in the late 1990s has had a tremendous impact on educational technology. Users could use computers to contact other computers and persons through computer-mediated communications (CMC) like email and chat rooms. Two movements have arisen regarding the creation of instructional media. The first being the new iteration of the creative individual producing his own resources and maintaining it on the web while the other being the industrial track where professionals engage in educational web environments.

The Internet has facilitated a new type of electronic learning, simply termed elearning. E-learning can be seen as the latest extension of technology in education and includes earlier computer-based technologies. There are many facets of elearning. A glimpse of an e-learning system could contain courseware, a learning management system, library and digital resources and learner support services (Davis 2004). Indeed, e-learning consists of collaborative technology, Internet technology, human computer interaction, multimedia technology, accounting, knowledge management, security, and telecommunication technology (Zhang \& Nunamaker 2003). 
E-learning extends CAI by adding the communication element to the previously individualized experience (Piccoli et al 2001). A highly embraced strength of e-learning is the capacity for increased interaction. Not solely an interaction between the student and the system, e-learning allows communication between peers and instructors and even collaborative learning communities. Elearning also provides high levels of student control and supports participant contact and interaction continuously during the learning process.

As educational technology progressed, the goals in using IT changed too. As mentioned, the initial idea of educational technology was that it was an effective tool for learning. Later on, researchers realized that IT was not beneficial unless it was designed and used in ways that enhanced learning. The emphasis of educational technology has thus shifted away from the equipment. The focus is now on the technology of education where the goal is to improve learning and teaching based on educational psychology and pedagogy.

The Internet has facilitated a new type of electronic learning, simply termed elearning. E-learning can be seen as the latest extension of technology in education and includes earlier computer-based technologies. There are many facets of elearning. A glimpse of an e-learning system could contain courseware, a learning management system, library and digital resources and learner support services (Davis 2004). Indeed, e-learning consists of collaborative technology, Internet technology, human computer interaction, multimedia technology, accounting, knowledge management, security, and telecommunication technology (Zhang \& Nunamaker 2003). These various aspects of e-learning are shown in Figure 1 (Zhang \& Nunamaker, 2003, p.212).

E-learning extends CAI by adding the communication element to the previously individualized experience (Piccoli et al 2001). A highly embraced strength of e-learning is the capacity for increased interaction. Not solely an interaction between the student and the system, e-learning allows communication between peers and instructors and even collaborative learning communities. Figure 2 illustrates the various ways of interaction (adapted from Shale \& Garrison 1990). E-learning also provides high levels of student control and supports participant contact and interaction continuously during the learning process.

As educational technology progressed, the goals in using IT changed too. As mentioned, the initial idea of educational technology was that it was an effective tool for learning. Educators concentrated on teaching discrete knowledge and basic skills to students through drill-and-practice applications of computers (Stites 2004). Also, educators transported teaching practices from the face-to-face classroom to the virtual classroom. Later on, researchers realized that IT was not beneficial unless it was designed and used in ways that enhanced learning. Moreover, IT had the potential to facilitate higher-order learning, problem solving, creativity, and integrated skills development (Stites 2004). Besides regarding IT as merely a tool, more and more educators and developers have realized the advantage of using technology as a learning strategy. Schunk (2004) suggests that IT should be implemented with learning goals in mind. The emphasis of educational technology has thus shifted away from the equipment. The focus is 
now on the technology of education where the goal is to improve learning and teaching based on educational psychology and pedagogy.

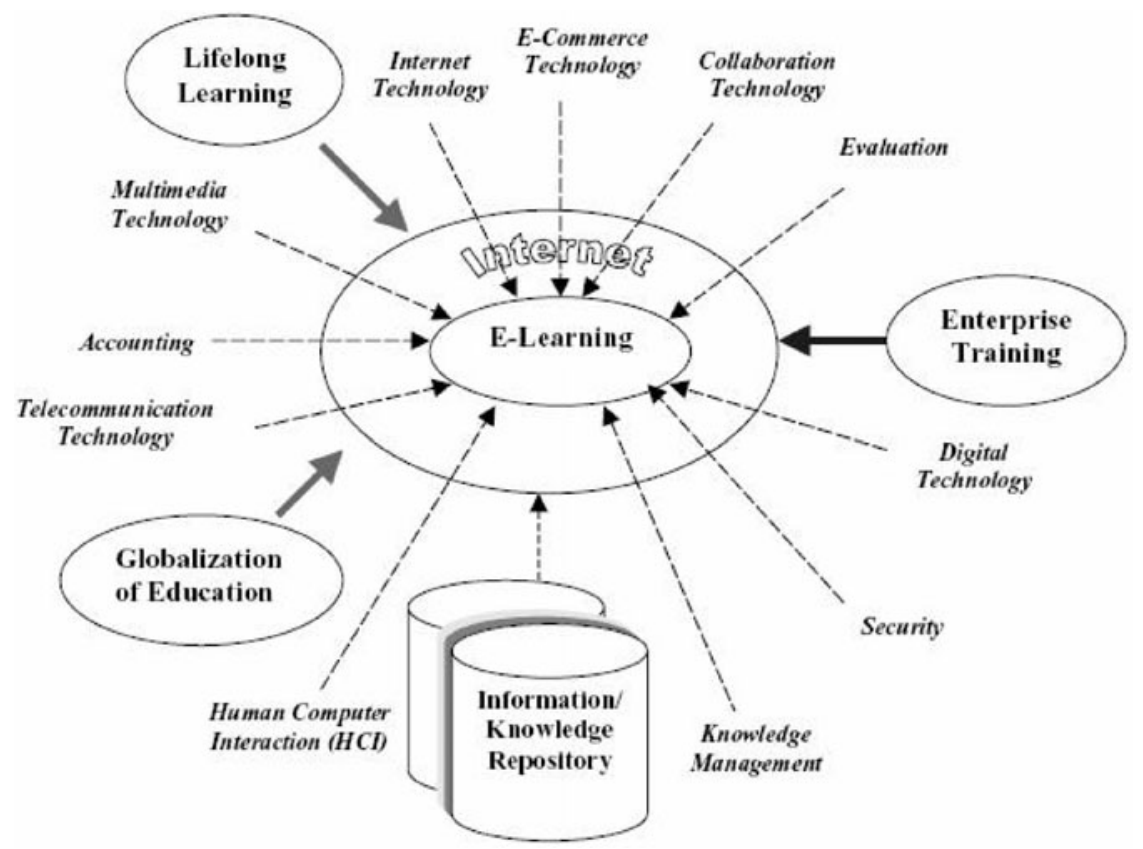

Figure 1 A framework of enabling technologies in e-learning

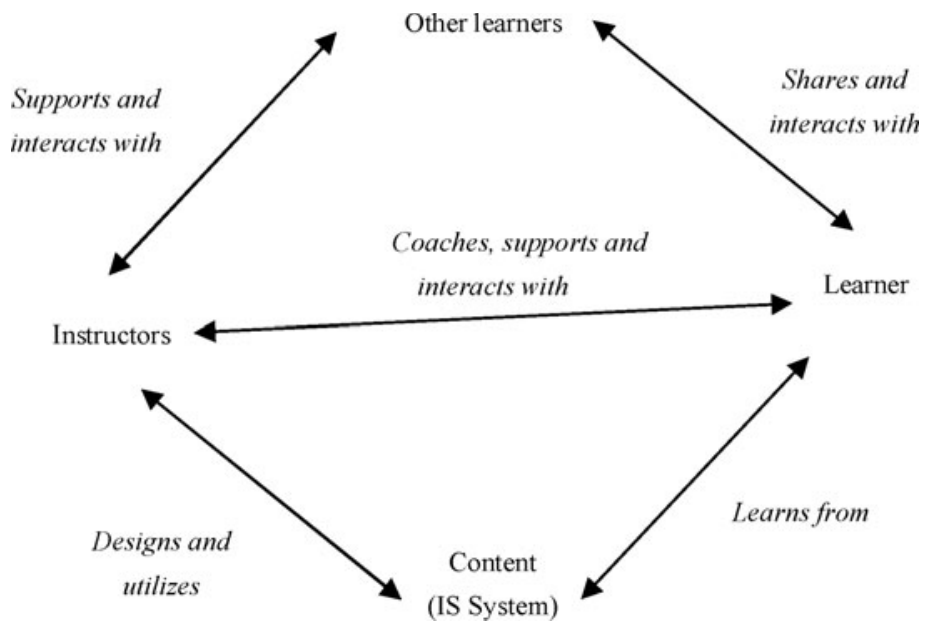

Figure 2 Elements of an e-learning system 


\subsection{The function of Pedagogy in Educational Technology}

Pedagogy or learning theories dovetail the educational systems in many cultures. These pedagogies are important factors that improve the effectiveness of educational technology. For example, Leidner and Jarverpaa (1995) and Piccoli and colleagues (2001) show support for improved learning outcomes when learning theory was incorporated in the design and application of e-learning systems. As mentioned earlier, three influential theories of learning have arisen behaviorism, cognitivism and constructivism. These theories are summarized in Table 3 (adapted from Driscoll \& Carliner, 2005).

These learning theories have been utilized in educational technology for better learning. A conceptualization of the use of these pedagogies in educational technology is termed the generations' view (Garrison \& Anderson 2003). Originally a scheme to classify distance education technologies, it can also be used as a general framework to trace the intertwining of pedagogy and educational technology.

The first generation is based on the behaviourist model of learning. This generation of educational tools created instructional material that had high standards that "could be delivered cost effectively to many thousands of students" (Garrison \& Anderson 2003, p.37). Students learn from preconceived educational objectives. Educational technology of this first generation are mostly independent study types - that is, students work with the computer alone at their own time. However, content is totally derived from the instructional material and do not make use of resources available on the Internet. These tools are known simply as CAI and were the most used application in schools in the 1990s (Schunk 2004). It provides drill and practice programs which reinforce lessons for students, simulation activities for them to improve their decision-making or problemsolving skills and tutorials to teach new subject materials (Tomei 2005). CAI that is developed with behaviorist principles is able to command learners' attention, provide immediate feedback, and improve their learning (Schunk 2004).

The learning theory of cognitivism was prevalent in second-generation educational systems. These included broadcast media, advanced organizers, summary reflections, and self-paced tutorials. This generation reiterated the need for independent study. Often, these technologies were expensive which drove the need for large student populations to lower average costs and limited the reach of such second-generation courses. The higher costs of production and problems of distribution resulted in "the development of centralized and distributed libraries of educational objects, such as MERLOT (http://www.merlot.org)" (Garrison \& Anderson 2003). E-learning based on the cognitive model of learning imitated the way the brain thinks, i.e., cognitive development through the layout, presentation, sequencing, and delivery of new knowledge (Tomei 2005). Programs also proceed deductively from the general to the specific. 
Table 3 Summary of Learning Theories

\begin{tabular}{|c|c|c|c|}
\hline & Behaviorism & Cognitivism & Constructivism \\
\hline $\begin{array}{l}\text { How is learning } \\
\text { described? }\end{array}$ & $\begin{array}{l}\text { Change in probability } \\
\text { of particular behavior } \\
\text { occurring in } \\
\text { particular situation }\end{array}$ & $\begin{array}{l}\text { Change in knowledge } \\
\text { is stored in memory }\end{array}$ & $\begin{array}{l}\text { Change in meaning } \\
\text { constructed from } \\
\text { experience }\end{array}$ \\
\hline $\begin{array}{l}\text { What is the role of } \\
\text { the instructor? }\end{array}$ & $\begin{array}{l}\text { Provide a highly } \\
\text { structured } \\
\text { environment in which } \\
\text { to practice behaviors }\end{array}$ & $\begin{array}{l}\text { Structure and } \\
\text { organize information } \\
\text { to make the } \\
\text { processing more } \\
\text { efficient and effective }\end{array}$ & $\begin{array}{l}\text { Guide and provide } \\
\text { materials from which } \\
\text { learners can construct } \\
\text { knowledge }\end{array}$ \\
\hline $\begin{array}{l}\text { What is the role of } \\
\text { the learner and the } \\
\text { nature of knowledge? }\end{array}$ & $\begin{array}{l}\text { Learner is passive, an } \\
\text { empty vessel and } \\
\text { knowledge exists } \\
\text { independent of the } \\
\text { learner }\end{array}$ & $\begin{array}{l}\text { Learner is active but } \\
\text { knowledge is still } \\
\text { independent of } \\
\text { learner }\end{array}$ & $\begin{array}{l}\text { Learners are active } \\
\text { participants who } \\
\text { construct their own } \\
\text { knowledge }\end{array}$ \\
\hline $\begin{array}{l}\text { How does transfer } \\
\text { happen? }\end{array}$ & $\begin{array}{l}\text { When a correct } \\
\text { response is } \\
\text { demonstrated } \\
\text { following the } \\
\text { presentation of a } \\
\text { specific environment } \\
\text { stimulus. Emphasis is } \\
\text { on observable, } \\
\text { measurable behavior. }\end{array}$ & $\begin{array}{l}\text { When the learner } \\
\text { encodes and stores } \\
\text { information in } \\
\text { memory in a } \\
\text { meaningful way }\end{array}$ & $\begin{array}{l}\text { When the learner } \\
\text { builds a personal } \\
\text { interpretation of the } \\
\text { world based on his or } \\
\text { her experiences and } \\
\text { interactions }\end{array}$ \\
\hline $\begin{array}{l}\text { What types of } \\
\text { learning are best } \\
\text { explained? }\end{array}$ & $\begin{array}{l}\text { Teaching behaviors } \\
\text { that can be observed } \\
\text { or demonstrated }\end{array}$ & $\begin{array}{l}\text { Problem solving, } \\
\text { deep processing, } \\
\text { exploring, organizing } \\
\text { and synthesizing } \\
\text { content }\end{array}$ & $\begin{array}{l}\text { Higher order thinking } \\
\text { skills such as } \\
\text { analysis, synthesis, } \\
\text { and evaluation }\end{array}$ \\
\hline $\begin{array}{l}\text { What principles are } \\
\text { relevant? }\end{array}$ & $\begin{array}{l}\text { Reinforcement, } \\
\text { shaping, stimulus and } \\
\text { response }\end{array}$ & $\begin{array}{l}\text { Events of instruction, } \\
\text { types of learning, } \\
\text { learning hierarchies }\end{array}$ & $\begin{array}{l}\text { Collaborative } \\
\text { learning, learner- } \\
\text { centered instruction, } \\
\text { scaffolding, problem- } \\
\text { solving }\end{array}$ \\
\hline
\end{tabular}

The third generation educational system marks a change in direction to focus on interactivity. This was materialized either by means of asynchronous and synchronous communication technologies. Constructivism was the base pedagogy and through $\mathrm{CMC}$, students were able to construct shared realities and knowledge individually and in group settings. Weller (2000) developed an introductory course to the Internet embracing third generation principles for the Open University in the UK. Another initiative is the WebQuest model, an inquiryoriented activity in which students search and evaluate information from the web (Jonassen et al. 2000). Through the ability to click on a wide array of links, it allows learners to construct their own learning experiences and encourage the individualized leaning of the student. Moreover, groups are able to collaborate and learn through online collaborative tools like chatrooms, electronic forums, wikis, and other collaborative systems. 
Lastly, the fourth generation is a coalescence of the three key attributes of the Internet - "information retrieval of vast amounts of content, interactive capacity of $\mathrm{CMC}$ and the processing power of locally distributed processing via computerassisted programming" (Garrison \& Anderson 2003, p.38). Fourth generation types of educational systems include powerful packages and fully integrated learning systems such as Blackboard and Lotus Notes. In this generation, no dominant pedagogy exists but learning theories from behaviorism, cognitivism and constructivism are integrated to develop specific learning goals.

This generation view shows the utilization of pedagogy in educational technology. The function of learning theories in technology is then to provide sound principles to effectively teach and increase the learning of students. Combining the strengths of learning theories and IT is core to the mindset of the technology of education. In fact, this approach is prevalent among educators and instructional designers currently. Depending on the type of learning and learning goals, educators are designing educational software and e-learning systems that will enhance learning for learners based on pedagogy.

\section{Concluding Remarks}

In sum, this paper has traced the emergence of educational technology. It first proposes that culture has influenced what we understand in education and this development of educational technology is very much intertwined with culture. It goes on to describe the evolution of educational technology and the theoretical underpinnings alongside its development. This discourse has the following implications for practitioners and researchers. First, the importance of culture should not be ignored in the design and understanding of educational technology. As seen from the cultural basis of education and subsequently modern theories about educational technology, cultural roots do have an influence. Second, learning theories are crucial for the implementation of technology. Simply applying technology in education will not be beneficial for education. Rather, it is essential that supporting theories and frames of references are considered together with the technology. An example of such a framework is seen in Conole et al. (2004). It is hoped that educators and researchers will be cognizant of culture and learning theories as they continue to improve and gain new experiences from using IT in education.

\section{References}

1. Adelsberger, H, H., Collis, B. and Pawlowski, J. M. (2002). Handbook of information technologies for education and training. Springer, New York

2. Ausburn, L. (2004). Course design elements most valued by adult learners in blended online education environments: an American perspective. Educational Media International, 41(4), 327-337.

3. Boettcher, J. V., and Conrad R-M. (2004). Faculty guide for moving teaching and learning to the Web. League for Innovation in the Community College, Phoenix, AZ. 
4. Camp, J. and Fisher, E. (2002). Exploring the world of the ancient Greeks. Thames \& Hudson, London.

5. Castle, E.B. (1965) Ancient Education and Today. Penguin Books Ltd, England.

6. Cheng, K. \& Wong, K. (1996) School effectiveness in East Asia: concepts, origins and implications. Journal of Educational Administration, 34(5)

7. Cleverly, John. (1991) The Schooling of China, Allen and Unwin, North Sydney, Australia.

8. Cochrane, P. (1998). Exponential education. In M. Henry (Ed.), Using IT effectively: a guide to technology in the social sciences(pp.3-16),.UCL Press, London,.

9. Conole, G. M., Dyke, M. O., Seale, J. (2004) Mapping pedagogy and tools for effective learning design, Computers \& Education, 43(1-2), 17-33,

10. Cribiore, R. (2001). Gymnastics of the mind: Greek education in Hellenistic and Roman Egypt. Princeton University Press, Princeton, N.J.

11. Davis. A. (2004). Developing an Infrastructure for Online Learning. In T. Anderson and F. Elloumi (Ed), Theory and Practice of Online Learning (pp. 97-114). Athabasca University, Canada.

12. Driscoll, M. and Carliner, S. (2005). Advanced Web-based training strategies, Pfeiffer Publishing, San Francisco.

13. Duffy, T.M. and Jonassen, D.H. (1992) Constructivism and the technology of instruction: a conversation. Lawrence Erlbaum Associates Publishers, Hillsdale, N.J.

14. Ellington, H., Percival, F. and Race, P. (1993). Handbook of educational technology, Kogan Page, London.

15. Ellis, A. K., Cogan, J.J., and Howey, K.R. (1991). Introduction to the foundations of education. 3rd Edition, Prentice-Hall, New Jersey.

16. Ferrante, J. (2003) Sociology: A Global Perspective. Wadsworth/Thomson Learning, Belmont.

17. Garrison, D. R. and Anderson, T. (2003). E-learning in the 21st Century: A framework for research and practice. RoutledgeFalmer, London.

18. Gillespie, K.H. (1998) The Impact of Technology on Faculty Development, Life and Work. Jossey-Bass, San Francisco.

19. Gutek, G. L. (1997) Philosophical and ideological perspectives on education. Allyn and Bacon, Boston.

20. Honebein, P.C., Duffy, T.M. and Fishman, B.J. (1993). Constructivism and the Design of Learning Environments: Context and Authentic Activities for Learning. In T.M. Duffy, J. Lowyck, and D.H. Jonassen (eds.) Designing Environments for Constructivist Learning (pp. 87-108). bSpringer-Verlag, Berlin.

21. Jonassen, D.H., Hernandez-Serrano, J. and Choi, I. (2000) Integrating Constructivism and learning technologies. In J.M. Spector and T.M. Anderson (eds.) Integrated and Holistic Perspectives on Learning, Instruction and Technology (pp. 103-128). Kluwer Academic Publishers, Dordrecht, Netherlands.

22. Kinder, T. (2002) Are schools learning organizations. Technovation, 22(6), 2002, 385-404.

23. Leidner, D. E. and Jarvenpaa, S. L. (1995) The Use of Information Technology to enhance management school education: a theoretical view. MIS Quarterly,19(3), 256-291.

24. Matta, K.F. and Kern, G.M. "A framework for research in computer-aided instruction: challenges and opportunities," Computers and Education 13(1), 1989, pp. 77-84.

25. McLoughlin, C. (1999) Culturally Responsive Technology Use: Developing an On-line Community of Learners. British Journal of Educational Technology, 30(3), 231-243.

26. McPherson, M. and Nunes, M. B. (2004) Developing Innovation in Online Learning: An Action Research Framework. Routledge Falmer, London.

27. Pathak, A. (2002) Social Implications of Schooling: Knowledge, Pedagogy and Consciousness. Rainbow Publishers, India.

28. Piccoli, G., Ahmad, R. and Ives, B. (2001) Web-based virtual learning environments: A research framework and a preliminary assessment of effectiveness in basic IT skills training. MIS Quarterly, 25(4), 401-426.

29. Rosenberg, M.J. (2001) E-learning: Strategies for Delivering Knowledge in the Digital Age. McGraw-Hill, New York. 
30. Schunk, D. H. (2004) Learning theories: an educational perspective. Pearson Education, Upper Saddle River.

31. Sharma, G. R. (1987) Trends in contemporary Indian philosophy of education: a critical evaluation. Nirmal Publishers, New Delhi.

32. Stites, R. (2004) Implications of New Learning Technologies for Adult Literacy and Learning. In J. Comings, B. Garner and C. Smith (eds.) Review of adult learning and literacy, Vol. 4, Connecting research, policy, and practice. Lawrence Erlbaum, New Jersey.

33. Strijbos, J., Kirschner, P. A. and Martens, R. L. (2004) What we know about CSCL and implementing it in higher education. Kluwer Academic Publishers, Boston, Mass.

34. Taylor, J. and Furnham, A. Learning at Work: Excellent practice from best theory, Palgrave Macmillan, Great Britain, 2005.

35. Tomei, L. A. (2005) Taxonomy for the Technology Domain, Idea Group, Hershey, PA.

36. Turner, Y. and Acker, A. (2002) Education in the new China: shaping ideas at work. Ashgate Publishing Limited, Aldershot, England.

37. Weller, M. J. (2000) Creating a Large-scale, Third Generation, Distance Education Course. Open Learning, Volume 15, Number 3, 1 November 2000, 243-252

38. Williams, S. W. (2002) Instructional Design Factors and the Effectiveness of Web-Based Training/Instruction, ERIC, ED474156.

39. Zhang, D. and Nunamaker, J.K. (2003) Powering E-learning in the new millennium: an overview of e-learning and enabling technology. Information Systems Frontiers, 5(2), 207 218.

40. Zhang, D., Zhao, J. L., Zhou, L. and Nunamaker Jr, J. F. (2004) Can e-learning replace classroom learning? Communication of the ACM, 47 (5), 75-79. 